\title{
Sistem Informasi Perencanaan Pembelian Barang (Studi Kasus : Susan Gallery)
}

\author{
Adam Pratama1, Dewi Primasari², Fitrah Satrya Fajar Kusumah ${ }^{3}$ \\ ${ }_{1,2}^{3}$ Fakultas Teknik dan Sains, Prodi Teknik Informatika \\ adam.pratama168@gmail.com ${ }^{1}$ dewiprimasari2@yahoo.com ${ }^{2}$ fitrah.satry@gmail.com $^{3}$
}

\begin{abstract}
Abstrak
Sistem Informasi Perencanaan Pembelian Barang (Studi Kasus: Susan Gallery) Susan Gallery merupakan badan usaha yang bergerak di bidang penjualan barang furniture yang berlokasi di Kota Depok. Perencanaan pembelian barang di Susan Gallery masih menggunakan pencatatan rekap manual, sehingga masih sangat rentan terjadi kesalahan pencatatan. Berdasarkan latar belakang diatas adalah membuat sistem informasi yang mampu merencanakan pembelian barang, dan bisa mengetahui berapa banyak barang yang direncanakan untuk dibeli, sehingga dapat membantu Susan Gallery untuk merencanakan pembelian barang. Untuk perencanaan pembelian barang menggunakan metode Moving Average. Untuk pengembangan sistem menggunakan metode waterfall yang meliputi tahap perencanaan, tahap analisis, tahap desain, tahap implementasi, dan tahap pemeliharaan. Hasil dari sistem informasi perencanaan pembelian barang ini adalah berupa data untuk pembelian barang yang telah direncanakan. Manfaat sistem ini adalah untuk membantu Susan Gallery untuk mengetahui banyak barang yang direncanakan untuk dibeli.
\end{abstract}

Kata kunci-furniture, perencanaan, pembelian, moving average, waterfall

\begin{abstract}
Information System of Goods Purchasing Planning (Case Study : Susan Gallery). Susan Gallery is a business engaged in sale of furniture items located in Depok City. Goods Purchasing Planning at Susan Gallery still using manual recording, so it's still very vulnerable to errors. Based on problem, how to making an information system that able to planning goods purchasing, and know how many items are planned to be purchased, so that it can help Susan Gallery to plan goods purchasing. For planning the goods purchasing is using Moving Average method. For system development is using waterfall method which includes planning, analysis, design, implementation, and maintenance phases. The results of the information system goods purchasing planning is in the form of data for the purchase of goods that have been planned. The benefit of this system is to help Susan Gallery and to find out how many items planned to be purchased.
\end{abstract}

Keyword furniture, planning, purchasing, moving averages, waterfall

\section{PENDAHULUAN}

Furniture adalah istilah yang digunakan untuk perabot rumah tangga yang berfungsi sebagai tempat penyimpanan barang, tempat duduk, tempat tidur, tempat mengerjakan sesuatu dalam bentuk meja, atau menaruh barang di permukaannya. Contoh dari produk furniture adalah lemari, meja, kursi, dan sofa. [1] Untuk membuka sebuah toko furniture dibutuhkan barang-barang yang cukup.
Setiap barang furniture memiliki jenis-jenis yang berbeda-beda.

Susan Gallery merupakan badan usaha yang bergerak di bidang penjualan barang furniture yang berlokasi di Kota Depok. Jenis barang furniture yang di jual di Susan Gallery adalah lemari, kursi, meja, dan sofa. Sebagai usaha dibidang furniture, Susan Gallery selalu melakukan perencanaan pembelian barang untuk ketersediaan produk di toko. Permasalahan di Susan Gallery adalah untuk perencanaan pembelian barang 
masih menggunakan pencatatan rekap manual, sehingga masih sangat rentan terjadi kesalahan pencatatan yang bisa berakibat apabila laporan rekap barang salah mencatat dan membeli barang yang tidak sesuai.

Metode yang digunakan untuk membuat aplikasi Sistem Informasi Perencanaan Pembelian Barang berbasis Web adalah Metode Moving Average. Metode moving average adalah metode yang menggunakan sejumlah data aktual permintaan yang baru untuk membangkitkan nilai ramalan untuk permintaan dimasa yang akan datang. [2]

Berdasarkan permasalahan tersebut, penulis ingin mencoba membuat aplikasi Sistem Informasi Perencanaan Pembelian Barang berbasis Web untuk mengatasi masalah untuk perencanaan pembelian barang furniture di Susan Gallery, sehingga dapat memudahkan usaha untuk perencanaan pembelian barang furniture.

\section{METODE PENELITIAN}

\subsection{Moving Averages}

Metode yang digunakan untuk merencanakan pembelian barang adalah metode moving averages. Metode moving averages adalah metode yang menggunakan sejumlah data aktual permintaan yang baru untuk membangkitkan nilai ramalan untuk permintaan dimasa yang akan datang.

\subsubsection{Cara Perhitungan Metode Moving Averages}

Untuk membuat forecast memerlukan data historis dalam jangka waktu tertentu, semakin panjang moving averages akan menghasilkan moving averages yang semakin halus, secara sistematis moving averages adalah:

$\mathrm{S} \mathrm{t}+1=(\Sigma \mathrm{t}+\mathrm{Xt}-1 \ldots \mathrm{Xt}-\mathrm{n}+1) / \mathrm{n}$

Dimana:

$\mathrm{S} \mathrm{t}+1=$ Forecast untuk periode $\mathrm{ke}$

$\mathrm{t}+1$

$\mathrm{Xt}=$ Data pada periode $\mathrm{t}$.

$\mathrm{n}=$ Jangka waktu moving averages.

Nilai $\mathrm{n}$ merupakan banyaknya periode dalam moving averages.
[2]

\subsection{Metode Waterfall}

Model waterfall atau biasa disebut klasik Life Cycle adalah model klasik yang bersifat sistematis, berurutan dalam membangun software. Nama model ini sebenarnya adalah "Linear Sequential Model". Model ini sering disebut dengan "classic life cycle" atau model waterfall. Model ini termasuk kedalam model generic pada rekayasa perangkat lunak sehingga sering dianggap kuno, tetapi merupakan model yang paling banyak dipakai dalam Software Engineering. Model ini melakukan pendekatan secara sistematis dan berurutan. Disebut dengan waterfall karena tahap demi tahap yang dilalui harus menunggu selesainya tahap sebelumnya dan berjalan berurutan. Tahapan utama dari model waterfall langsung mencerminkan aktifitas pengembangan dasar. [9]

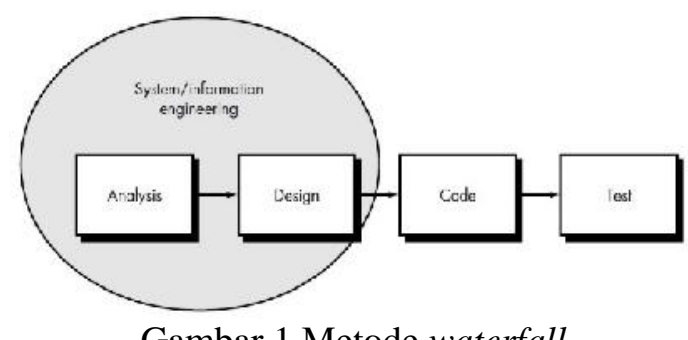

Gambar 1 Metode waterfall

Berikut adalah penjelasan dari tahapan-tahapan tersebut :

1. Rekayasa dan pemodelan sistem/informasi

Pada tahap ini penting karena perangkat lunak harus berhubungan dengan elemen-elemen yang lain seperti perangkat keras, manusia atau pemakai, dan basis data.

2. Analisis kebutuhan perangkat lunak Tahap ini untuk memahami sifat program yang dibangun, maka perlu dipahami domain informasi, tingkah laku, kinerja, dan antarmuka (interface) yang diperlukan.

3. Desain

Proses ini berfokus pada struktur data, arsitektur perangkat lunak, antarmuka, dan algoritmanya atau prosedur.

4. Penerjemah kode (Code Generation) 
Rancangan atau desain yang telah dibuat harus diterjemahkan ke dalam bentuk yang dapat dimengerti oleh mesin.

5. Pengujian (Testing)

Tahap ini bertujuan untuk memastikan bahwa semua pernyataan sudah diuji, untuk menemukan kesalahankesalahan, dan untuk memastikan bahwa hasilnya sesuai dengan yang diharapkan oleh pelanggan.

\subsection{Waktu dan Tempat Penelitian}

Penelitian dilakukan di Susan Gallery yang beralamat di Jl. Bhakti ABRI No.99 Kelurahan Sukamaju Baru, Kecamatan Tapos, Kota Depok, dari 22 Oktober 2017 sampai dengan 22 November 2017.

Alat yang digunakan terbagi menjadi 2 (dua) jenis, yaitu perangkat keras (hardware), dan perangkat lunak (software).

1. Perangkat keras (hardware).
a. Sebuah laptop Lenovo I deapad 320:
b. Printer Canon Pixma IP2770.
c. Modem Huawei.
d. Mouse nirkabel Genius.

2. Perangkat lunak (software).
a. Sistem operasi Windows 10 64 bit.
b. XAMPP v.3.2.2.
c. Adobe XD
d. Microsoft Office Word 2016.
e. Sublime text editor.
f. Codeigniter version 3 .

\subsection{Metode Pengembangan Sistem}

Metode pengembangan sistem yang digunakan untuk pembuatan Sistem Informasi Perencanaan Pembelian Barang di Susan Gallery adalah Metode Waterfall, Metode Waterfall meliputi lima tahapan sebagai berikut:

1. Tahap Perencanaan

Tahap ini menjelaskan secara singkat tentang pembuatan Sistem Informasi Perencanaan Pembelian Barang.

2. Tahap Analisis
Tahap ini menjelaskan kebutuhan yang diperlukan dalam pembuatan Sistem Informasi Perencanaan Pembelian Barang.

3. Tahap Desain

Tahap ini menjelaskan desain/rancangan pembuatan Sistem Informasi Perencanaan Pembelian Barang sebelum memulai tahap implementasi. Dalam fase ini dijelaskan pada bagian Use Case Diagram, struktur Database, dan tampilan Interface.

4. Tahap Implementasi

Tahap ini menjelaskan implementasi yang dilakukan terhadap sistem yang dibuat. Proses ini adalah pelaksanaan dari tahap analisis dan desain. Tahap ini juga menjelaskan hasil sistem yang telah dibuat.

5. Tahap Pemeliharaan

Tahap ini dilakukan setelah pembuatan Sistem Perencanaan Pembelian Barang telah selesai dilakukan. Tahap ini meliputi pemeliharaan sistem dan database untuk menjaga kinerja sistem.

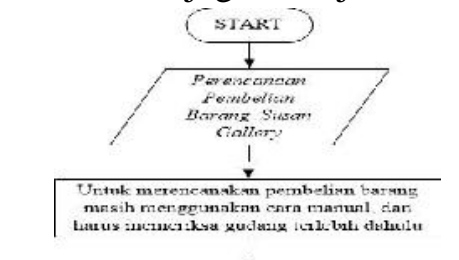

1
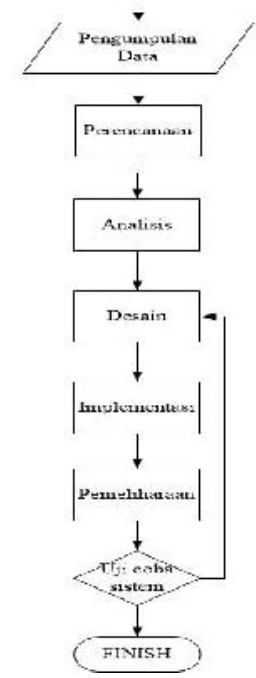

Gambar 3 Metode Pengembangan

\subsection{Analisis Data}

Data Bahan yang digunakan adalah data-data laporan rekap keluarmasuk barang tahun 2017 
Tabel 1 Sampel Data Keluar Masuk

Barang

\begin{tabular}{|l|l|l|}
\hline No. & Bulan & Penjualan \\
\hline 1. & Juli & 4 \\
\hline 2. & Agustus & 28 \\
\hline 3. & September & 24 \\
\hline 4. & Oktober & 18 \\
\hline 5. & November & 20 \\
\hline 6. & Desember & 22 \\
\hline
\end{tabular}

$\mathrm{St}+1=(\Sigma \mathrm{t}+\mathrm{Xt}-1 \ldots \mathrm{Xt}-\mathrm{n}+1) / \mathrm{n}$

Dimana:

$\mathrm{S} \mathrm{t}+1=$ Forecast untuk periode ke $\mathrm{t}+1$.

$\mathrm{Xt}=$ Data pada periode $\mathrm{t}$.

$\mathrm{n}=$ Jangka waktu moving averages.

Perhitungan peramalan unit kursi model Damar Flamboyan adalah:

Bulan Januari $=$ $(4+28++24++18+20+22) / 6=116: 6$ $=19$

Tabel 2 Data Hasil Peramalan Sample

\begin{tabular}{|l|l|l|l|}
\hline $\begin{array}{l}\text { No } \\
(\mathbf{n})\end{array}$ & Bulan (t) & $\begin{array}{l}\text { Penjuala } \\
\text { n }(\mathbf{X t )}\end{array}$ & $\begin{array}{l}\text { Peramala } \\
\text { n (unit) }\end{array}$ \\
\hline 1. & Juli & 4 & - \\
\hline 2. & Agustus & 28 & - \\
\hline 3. & $\begin{array}{l}\text { Septembe } \\
\text { r }\end{array}$ & 24 & - \\
\hline 4. & Oktober & 18 & - \\
\hline 5. & $\begin{array}{l}\text { Novembe } \\
\text { r }\end{array}$ & 20 & - \\
\hline 6. & Desember & 22 & - \\
\hline 7. & Januari & - & 19 \\
\hline
\end{tabular}

3. HASIL DAN PEMBAHASAN
Analisis kebutuhan sistem adalah tahap untuk merencanakan sistem apa yang dibutuhkan dalam penyelesaian masalah.

\subsection{Proses Bisnis yang sedang Berjalan}

Berdasarkan hasil analisis proses bisnis yang sedang berjalan, prosedur untuk perencanaan pembelian barang dimulai dari pihak Staff Admin mencatat data barang terjual per-bulan. Setelah mencatat data barang terjual, lalu Staff Admin membuat laporan rekap barang (keluar-masuk barang) berdasarkan data dari catatan data barang terjual. Setelah itu pihak Gudang melihat barang apa yang masih tersisa di gudang. Setelah itu pihak Gudang membuat surat untuk penambahan barang yang ketersediaan sedikit atau barang yang sudah habis.

Surat itu lalu diberikan ke Staff Admin untuk memeriksa berdasarkan data laporan rekap barang apakah barang yang diminta untuk ditambah memang sangat dibutuhkan atau tidak. Setelah diperiksa lalu surat diberikan ke pimpinan untuk diminta persetujuan apakah pimpinan setuju untuk penambahan barang atau tidak. Jika setuju lalu pimpinan menandatangani surat rencana pembelian dan penambahan barang. Surat lalu diberikan kembali ke Staff Admin, lalu Staff Admin memesan barang sesuai dengan rencana pembelian. Setelah barang sampai

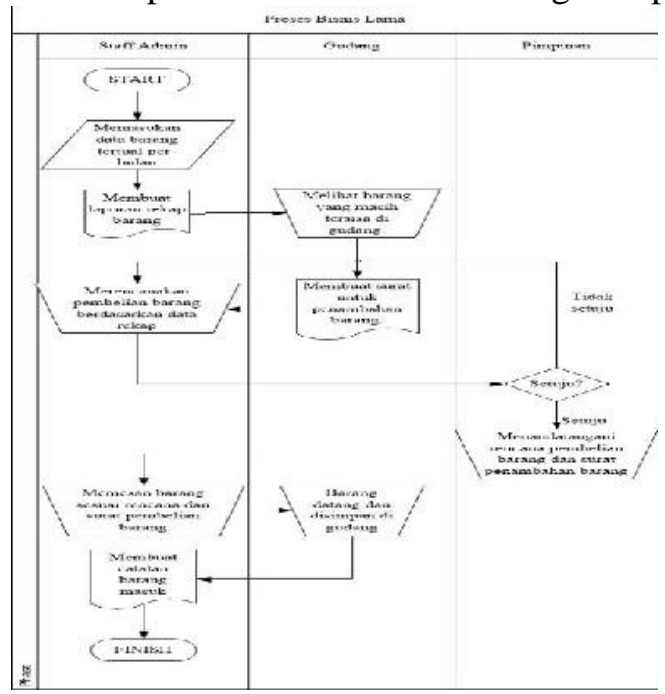

Gambar 4 Proses Bisnis yang sedang di Berjalan

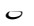

\subsection{Proses Bisnis Baru}


Berdasarkan hasil analisis proses bisnis yang sedang berjalan tersebut, maka dirancang sebuah proses bisnis baru yang bisa menjadi solusi akan permasalahan yang dialami dalam proses bisnis yang sedang berjalan.

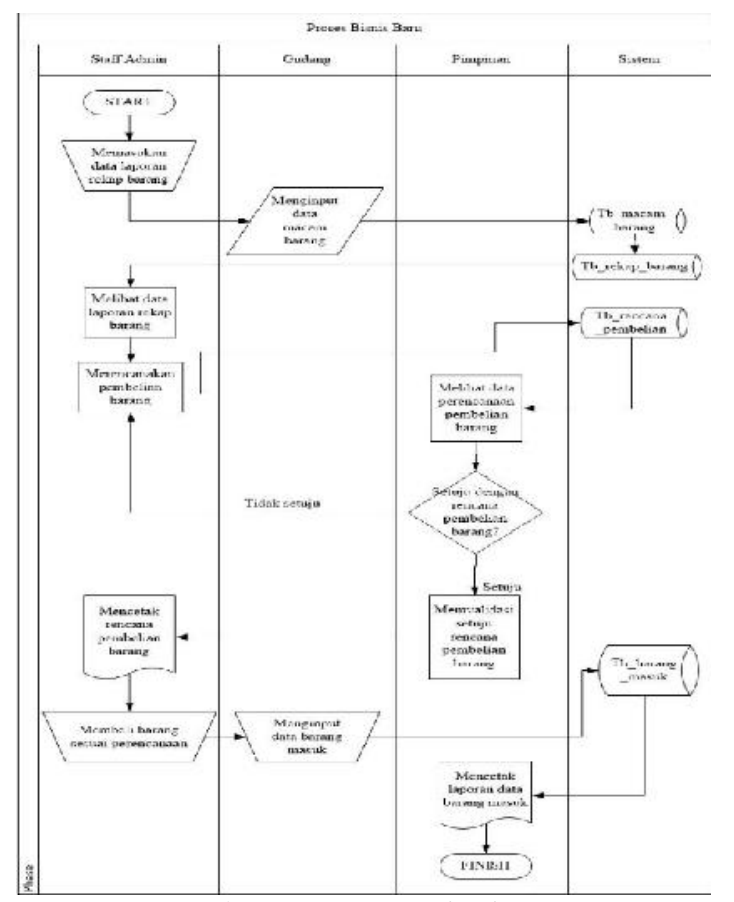

Gambar 4 Proses Bisnis Baru

Pada proses bisnis baru dapat dilihat untuk memasukan data laporan rekap barang Staff Admin hanya perlu mencari dalam database sistem apakah barang yang diisi telah ada, jika belum ada maka Gudang akan menginput data macam barang yang belum terdaftar tersebut. Setelah itu Staff Admin bisa langsung merencanakan pembelian barang berdasarkan data laporan rekap barang yang sudah diinput. Setelah direncanakan lalu Staff Admin simpan di database sistem. Tugas Pimpinan hanya melihat rencana pembelian barang dan memutuskan apakah setuju dengan rencana pembelian atau tidak. Jika setuju maka pimpinan memvalidasi setuju, jika tidak setuju Pimpinan memvalidasi tidak setuju. Setelah divalidasi maka hasil validasi dari Pimpinan bisa Staff Admin cetak untuk membeli barang. Setelah barang sampai, Gudang lalu menginputkan data laporan barang masuk untuk disimpan dalam database sistem. Lalu pimpinan tinggal mencetak laporan barang masuk.
Diagram konteks adalah gambaran mengenai sistem secara umum. Diagram konteks meliputi pengguna melakukan suatu proses ke sistem, dan feedback yang diterima oleh pengguna dari sistem.

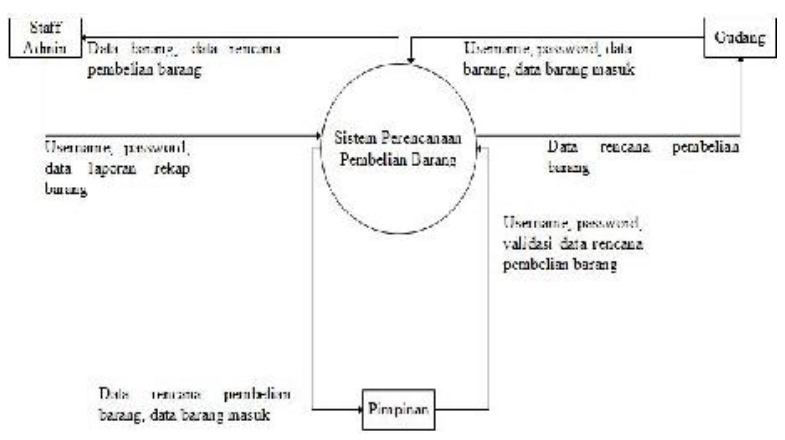

Gambar 5 Diagram konteks

Diagram use case adalah gambaran kerja sistem berdasarkan aktor yang berperan.

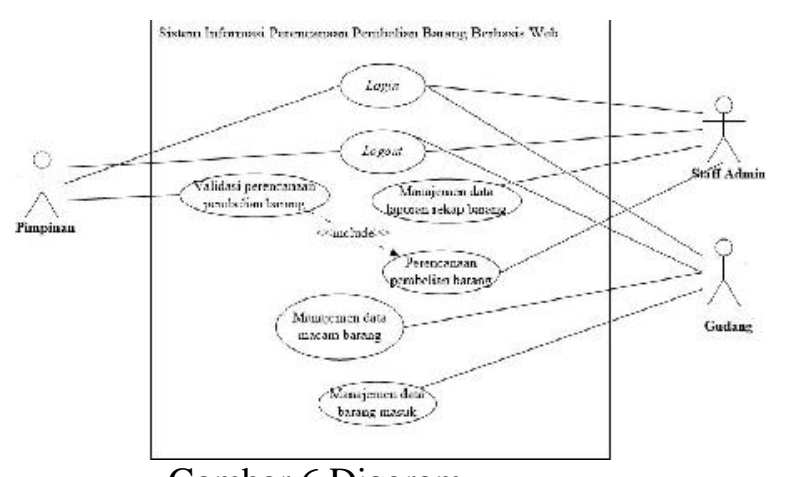

Gambar 6 Diagram usecase

Diagram Class merupakan sebuah spesifikasi yang jika diinstanisasi akan menghasilkan sebuah objek dan merupakan inti dari pengembangan dan desain beriorientasi objek. Diagram Class menggambarkan atribut suatu sistem, sekaligus menawarkan layanan untuk memanipulasi keadaan tersebut (metode/fungsi).

\subsection{Perancangan Sistem}




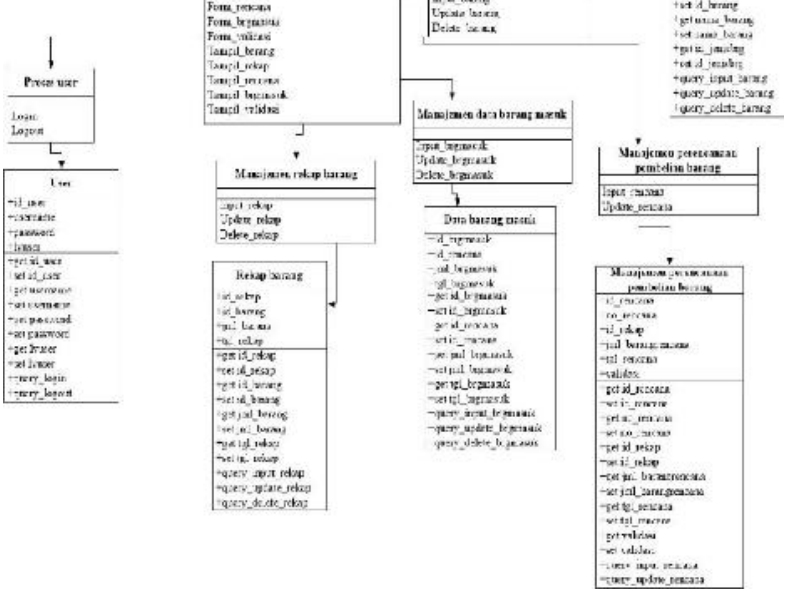

Gambar 7 Diagram class

Diagram Deployment adalah diagram yang menggambarkan detail bagaimana komponen di-deploy dalam infrastruktur sistem, konfigurasi sistem informasi perencanaan pembelian barang yang dijelaskan pada web server dan database server.

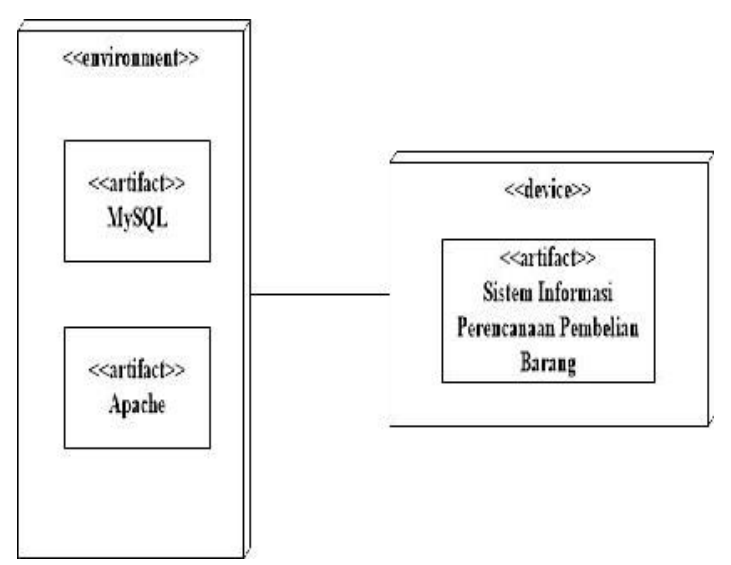

Gambar 8 Diagram Deployment

Diagram Component adalah diagram yang menampilkan komponen dalam sistem dan hubungan antar mereka. Diagram Component digunakan untuk menjelaskan ketergantungan antara beragam komponen perangkat lunak seperti ketergantungan antara file executable dengan file source, dan lain-lain.

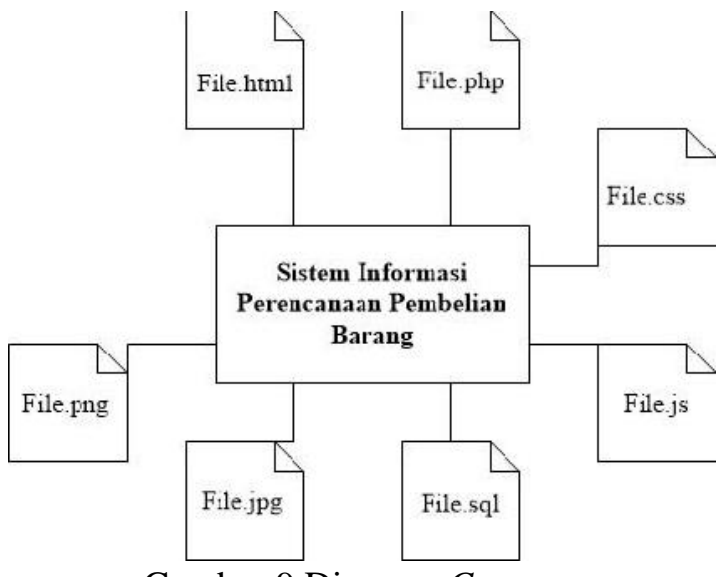

Gambar 9 Diagram Component

Desain database bertujuan untuk mengelola data yang sudah dioleh maupun untuk menampilkan data yang dibutuhkan oleh aplikasi.

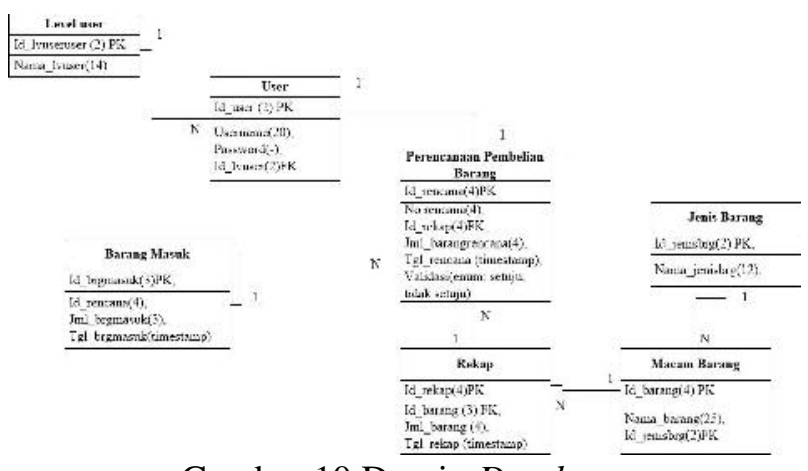

Gambar 10 Desain Database

\subsection{Implementasi Sistem}

Implementasi merupakan bagian penerapan perancangan, desain sistem dan pengkodean pada sistem serta melakukan pengujian terhadap penerapan sistem. Tahapan implementasi pada sistem ini menggunakan Bahasa pemrograman HTML, CSS, Javascript dan PHP.

\section{Menu Login}

Menu login merupakan menu yang pertama kali dilihat saat membuka sistem. Menu login berfungsi sebagai gerbang untuk masuk ke dalam sistem. 


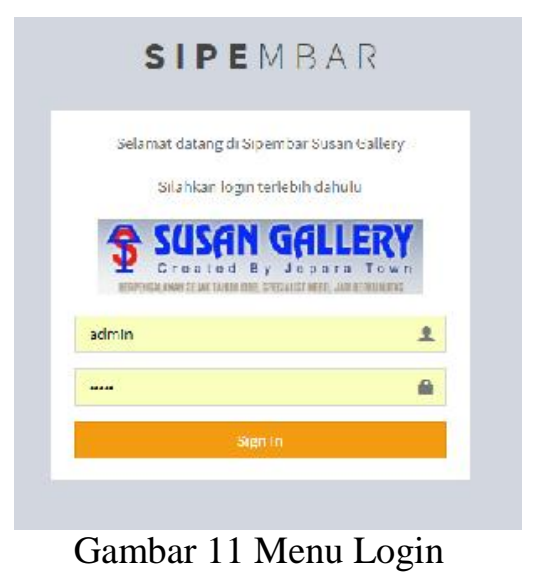

Menu logout merupakan menu yang berfungsi untuk keluar dari sistem.

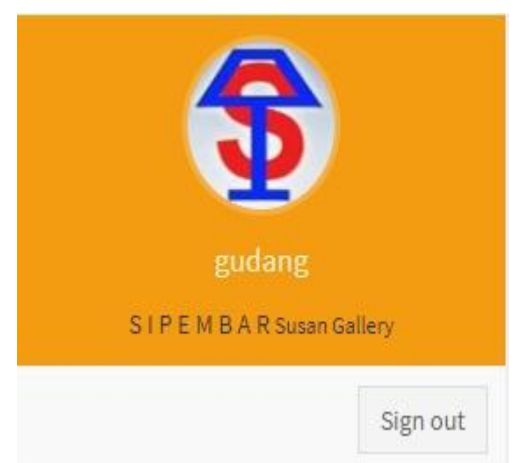

Gambar 12 Menu Logout

Menu manajemen data laporan rekap barang adalah menu untuk menyimpan datadata barang yang tersimpan. Menu manajemen data laporan rekap barang hanya bisa di-akses oleh pengguna staff-admin.

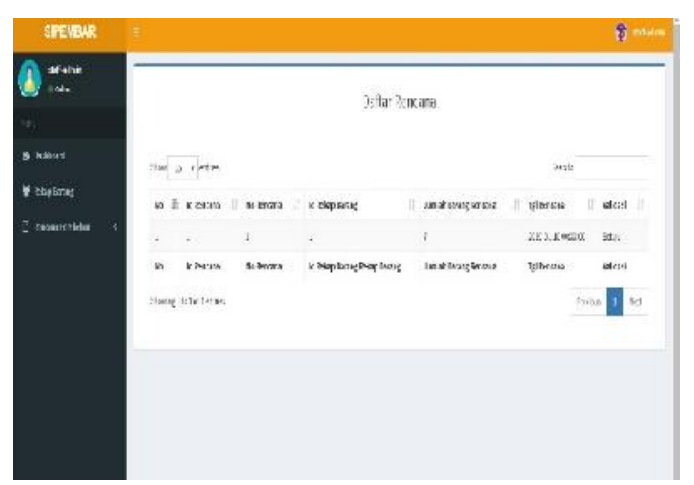

Gambar 13 Menu Manajemen Data Laporan Rekap Barang

Menu perencanaan pembelian barang adalah menu untuk merencanakan pembelian barang berdasarkan data rekap barang. Menu perencanaan pembelian barang hanya bisa diakses oleh pengguna staff-admin.

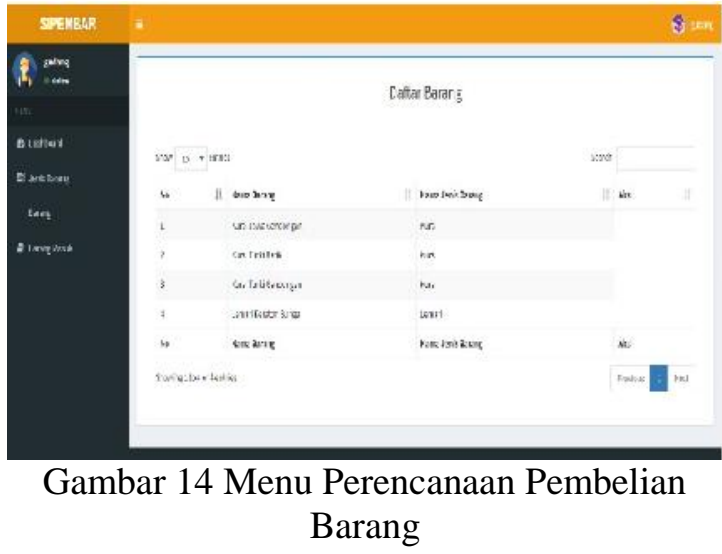

Menu validasi perencanaan pembelian adalah menu untuk memvalidasi perencanaan pembelian barang apakah rencana pembelian barang itu disetujui atau tidak. Menu validasi perencanaan pembelian barang hanya bisa di-akses oleh pengguna pimpinan.

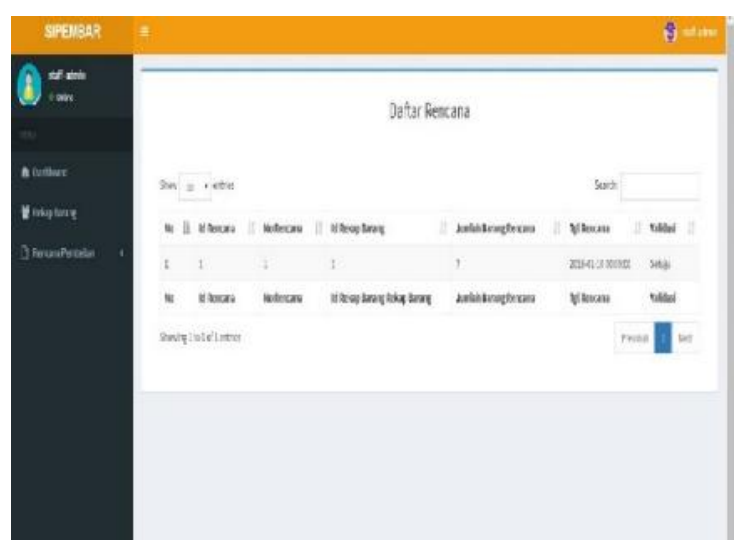

Gambar 15 Menu Validasi Perencanaan Pembelian Barang

Menu manajemen data macam barang adalah menu untuk menambahkan, mengedit, atau menghapus data-data jenis dan macam barang. Menu manajemen data barang hanya bisa di-akses oleh pengguna gudang. 


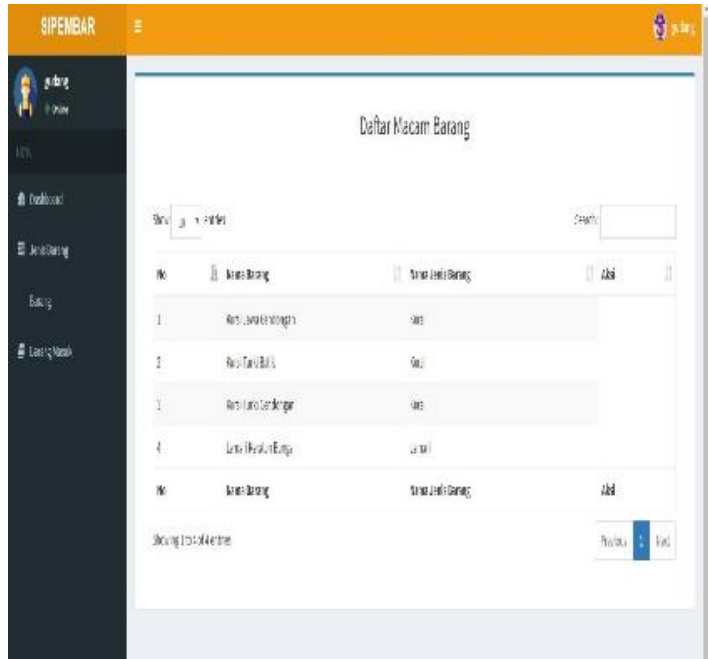

Gambar 16 Menu Manajemen Data Barang

Menu manajemen data barang masuk adalah menu yang berfungsi untuk memasukan data barang-barang yang telah masuk ke dalam gudang setelah pembelian barang. Menu manajemen data barang masuk hanya bisa di-akses oleh pengguna gudang.

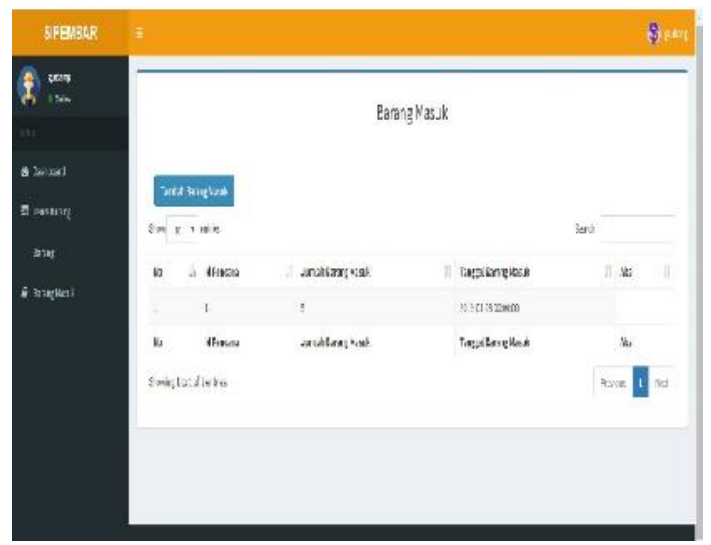

Gambar 17 Menu Manajemen Data Barang Masuk

\subsection{Pengujian}

Pengujian merupakan tahapan untuk menguji kesesuaian sistem terhadap desain dan pengkodean yang telah diimplementasikan . Pengujian pada sistem ini dilakukan menggunakan pengujian blackbox.

Tabel 3 Pengujian

\begin{tabular}{|l|l|l|l|}
\hline Form Uji & $\begin{array}{l}\text { Skenario } \\
\text { Uji }\end{array}$ & $\begin{array}{l}\text { Ekspetasi } \\
\text { Hasil }\end{array}$ & Hasil Uji \\
\hline Login & $\begin{array}{l}\text { Menginput } \\
\text { username } \\
\text { dan } \\
\text { password } \\
\text { yang sesuai. }\end{array}$ & $\begin{array}{l}\text { Masuk ke } \\
\text { dalam } \\
\text { sistem. }\end{array}$ & Berhasil. \\
\hline
\end{tabular}

\begin{tabular}{|l|l|l|l|}
\hline Logout & $\begin{array}{l}\text { Mengklik } \\
\text { tombol } \\
\text { logout. }\end{array}$ & $\begin{array}{l}\text { Keluar dari } \\
\text { sistem. }\end{array}$ & Berhasil. \\
\hline $\begin{array}{l}\text { Rekap } \\
\text { barang }\end{array}$ & $\begin{array}{l}\text { Membuka } \\
\text { menu rekap } \\
\text { barang. }\end{array}$ & $\begin{array}{l}\text { Masuk ke } \\
\text { menu rekap } \\
\text { barang. }\end{array}$ & Berhasil. \\
\hline $\begin{array}{l}\text { Rencana } \\
\text { pembelian }\end{array}$ & $\begin{array}{l}\text { Membuka } \\
\text { menu } \\
\text { rencana } \\
\text { pembelian. }\end{array}$ & $\begin{array}{l}\text { Masuk ke } \\
\text { menu } \\
\text { rencana } \\
\text { pembelian. }\end{array}$ & Berhasil. \\
\hline $\begin{array}{l}\text { Validasi } \\
\text { rencana } \\
\text { pembelian }\end{array}$ & $\begin{array}{l}\text { Membuka } \\
\text { menu } \\
\text { validasi } \\
\text { rencana } \\
\text { pembelian. }\end{array}$ & $\begin{array}{l}\text { Masuk ke } \\
\text { menu } \\
\text { validasi } \\
\text { rencana } \\
\text { pembelian. }\end{array}$ & Berhasil. \\
\hline $\begin{array}{l}\text { Macam } \\
\text { barang }\end{array}$ & $\begin{array}{l}\text { Membuka } \\
\text { menu macam } \\
\text { barang. }\end{array}$ & $\begin{array}{l}\text { Masuk ke } \\
\text { menu } \\
\text { macam } \\
\text { barang. }\end{array}$ & Berhasil. \\
\hline $\begin{array}{l}\text { Barang } \\
\text { masuk }\end{array}$ & $\begin{array}{l}\text { Membuka } \\
\text { menu barang } \\
\text { masuk. }\end{array}$ & $\begin{array}{l}\text { Masuk ke } \\
\text { menu } \\
\text { barang } \\
\text { masuk. }\end{array}$ & Berhasil \\
\hline
\end{tabular}

\section{KESIMPULAN DANS SARAN}

1. Dengan adanya Sistem Informasi Perencanaan Pembelian Barang ini adalah untuk mengatasi masalah untuk perencanaan pembelian barang di Susan Gallery, sehingga dapat memudahkan usaha Susan Gallery dalam segi produktivitas.

2. Berdasarkan dengan model data yang telah penulis analisis, Susan Gallery merencanakan pembelian barang di tiap 6 bulan. Dengan metode Moving Averages, Susan Gallery dapat merencanakan berapa banyak barang yang akan dibeli.

3. Sistem ini telah diuji dengan menggunakan pengujian blackbox.

Sistem Informasi Perencanaan Pembelian Barang ini membutuhkan beberapa tambahan diantaranya adalah :

1. Tampilan yang lebih baik agar terlihat menarik.

2. Menambahkan fitur pemilihan supplier agar mengetahui ditempat mana untuk membeli barang.

\section{UCAPAN TERIMAKASIH}

1. Kedua Orang Tua yang telah memberikan dukungan baik moril 
maupun materil yang sangat penulis butuhkan dalam penyelesaian laporan tugas akhir ini.

2. Bapak Dr. H. Yogi Sirodz Gaos, Ir, M.T. selaku Dekan Fakultas Teknik Universitas Ibn Khaldun, Bogor.

3. Bapak Ade Hendri Hendrawan, S.Kom, M.Kom selaku Kepala Program Studi Teknik Informatika Universitas Ibn Khaldun, Bogor.

4. Ibu Puspa Eosina, S.Si, M.Kom, selaku Kepala Laboratorium Sistem Informasi di Teknik Informatika Universitas Ibn Khaldun.

5. Ibu Dewi Primasari, S.Si., M.M. selaku Dosen Pembimbing Utama dalam penyelesaian tugas akhir ini.

6. Bapak Fitrah Satrya Fajar Kusumah, S.Kom, M.Kom. selaku Dosen Pembimbing Pendamping dalam penyelesaian tugas akhir ini.

7. Bapak Abdul Rahman selaku manager di Susan Gallery yang telah memberikan penulis izin untuk melaksanakan penelitian tugas akhir di Susan Gallery.

8. Teman-teman Teknik Informatika 2014 khususnya Diky Ibrahim, Meivan Agung Prasetyo, dan Hardiansyah yang telah banyak membantu penulis dalam mengerjakan tugas akhir.

9. Teman-teman Sistem Informasi 2014 khususnya Septian Isnanto, Arie Setiawan, Yulia Ake Panama, dan Desi Indriani Lestari yang telah banyak membantu penulis untuk mendapatkan informasi untuk tugas akhir.

10. Muhammad Suwana, sebagai rekan saya dalam mengerjakan tugas akhir, yang telah banyak membantu penulis dalam penyelesaian tugas akhir ini.

11. Teman-teman KINS yang telah mewarnai kehidupan kuliah penulis dari awal kuliah sampai selesainya penulisan laporan tugas akhir ini.

12. Indri Aprilia, Noviana Syahfitri, Mega Utami, Julia Wahyu Chandra, Muhammad Firdaus (Bang Ipang), Arif Supriyatna (Bang Bule) dan teman-teman lain yang selalu memberi bantuan baik moril maupun materil kepada penulis.
13. Keluarga penulis, terutama adik-adik penulis yang sangat penulis sayang.

\section{DAFTAR PUSTAKA}

[1] Postel, Jim, Furniture Design 2nd edition, USA: John Willey \& Sons, Inc, 1958

[2] S. Agung, Akbar, Penerapan Metode Single Moving Average dan Exponential Smoothing dalam Peramalan Permintaan Produk Meubel Jenis Coffee Table pada Java Furniture, Klaten, Surakarta:Universitas Sebelas Maret, 2009.

[3] F. Nash, John, diterjemahkan oleh La Midjan, Pengertian Sistem Informasi, Jakarta: Informatika, 1995.

[4] Assauri, Sofjan, Manajemen Produksi dan Operasi:Edisi revisi 2008, Jakarta: Lembaga Penerbit Fakultas Ekonomi Universitas Indonesia, 2008.

[5] Imbar Victor, Radiant dan Yon Andreas, Aplikasi Peramalan Stok Barang Menggunakan Double Exponential Smoothing, Bandung:Universitas Kristen Maranatha. 2012.

[6] R. Astamal, Mastering Kode HTML, Surabaya: rahasia-webmaster.com, 2006.

[7] Nurcholish, Ahmad, Membangun database arsip persuratan menggunakan pemrograman PHP dan Mysql: studi kasus pada Kantor Balai Taman Nasional Gunung Rinjani, Sukabumi: CV. Jejak, 2018.

[8] Whitten J, System Analysis And Design Methods, New York: Mc Graw-Hill Irwin, 2007.

[9] Pressman R, Software Engineering: A Practitioner's Approach, New York: McGraw-Hill Book Company, 2001. 